\title{
PENGEMBANGAN BAHAN AJAR PERKALIAN DAN PEMBAGIAN DENGAN MENGADOPSI OPERASI ARITMATIKA BANGSA MESIR KUNO
}

\author{
Attin Warmi ${ }^{1}$ \\ ${ }^{1}$ Program Studi Pendidikan Matematika, Fakultas Keguruan dan Ilmu Pendidikan \\ Universitas Singaperbangsa Karawang \\ 1attin.warmi@yahoo.com
}

\begin{abstract}
This program is one of the community service programs carried out by groups of lecturers and student representatives of the mathematics education program at UNSIKA. This program is in the form of providing tutoring outside school hours to elementary school students in mathematics. Most students are of the view that mathematics is difficult. Based on these conditions, we will design a program to help the school in providing tutoring to students in dealing with students to facilitate learning multiplication and division. The form of the program is in the form of providing tutoring for elementary school students, to facilitate student learning in completing multiplication and division operations. For the implementation of this activity, the mathematics textbooks and modules that are designed for guidance and study must be prepared. The material to be applied is about mathematical materials that have been summarized relating to multiplication and division operations. The structure of teaching materials for each topic starts with concepts, examples of questions, exercises, discussions and key answers. The textbook is ready to be used for the program.
\end{abstract}

Keywords: tutoring, addition, division

\begin{abstract}
Abstrak
Program ini merupakan salah satu program pengabdian masyarakat yang dilaksanakan oleh kelompok dosen dan perwakilan mahasiswa program studi pendidikan matematika UNSIKA. Program ini berupa pemberian bimbingan belajar diluar jam sekolah kepada siswa siswi sekolah Dasar pada pelajaran matematika. Kebanyakan siswa berpandangan bahwa matematika itu sulit. Berdasarkan kondisi tersebut, kami akan merancang program untuk membantu pihak sekolah dalam pemberian bimbingan belajar untuk siswa siswinya dalam menghadapi siswa untuk mempermudah belajar perkalian dan pembagian. Bentuk dari programnya adalah berupa pemberian bimbingan belajar untuk siswa siswi sekolah dasar, untuk mempermudah siswa siswi belajar dalam menyelesaikan operasi perkalian dan pembagian. Untuk terlaksananya kegiatan ini yang harus dipersiapkan adalah buku ajar matematika dan modul yang dirancang untuk selama bimbingan belajar. Materi yang akan di terapkan yaitu tentang materi-materi matematika yang sudah dirangkum yang berkenaan dengan operasi perkalian dan pembagian. Struktur bahan ajar untuk setiap topik yaitu dimulai dengan konsep, contoh soal, latihan, pembahasan dan kunci jawaban. Buku ajar tersebut siap digunakan untuk program tersebut.
\end{abstract}

Kata Kunci: bimbingan belajar, penjumlahan, pembagian

\section{Pendahuluan}

Matematika sebagai salah satu ilmu dasar memegang peranan penting dalam berbagai aspek kehidupan manusia. Kebanyakan siswa berpandangan bahwa matematika itu sulit dipelajari dan didukung juga oleh pandangan masyarakat umum sehingga 
pelajaran matematika cenderung dihindari oleh siswa yang mengalami kesulitan belajar. Siswa mengalami kecemasan ketika berhadapan dengan pelajaran matematika. Kecemasan ini bila ditanggapi positif akan membuat meeka terdorong giat belajar, tapi sebaliknya jika ditanggapi negatif oleh siswa maka pelajaran matematika semakin tidak diminati.

Menurut Zulkardi, rendahnya prestasi dan negatifnya sikap murid khususnya terhadap matematika adalah disebabkan beberapa hal seperti: kurikulum yang padat, materi pada buku pelajaran yang dirasakan terlalu banyak dan sulit untuk diikuti, media belajar yang kurang efektif, metode pelajaran yang tradisional dan tidak interaktif, dan sistem evaluasi yang buruk.

Salah satu pelajaran yang dianggap sulit siswa adalah matematika. Masih bayak siswa yang mengalami kesulitan dalam operasi aritmatika yaitu pada perkalian dan pembagian. Menurut Gagne (dalam Sugiharto, 2003: 33), dalam belajar matematika ada dua objek yang dapat diperoleh siswa, yaitu objek langsung dan objek tak langsung. Objek langsung terdiri dari fakta, konsep, skill, dan prinsip. Begle dalam Hudojo (2005: 36) menyatakan bahwa sasaran atau objek penelaahan matematika adalah fakta, konsep, operasi, dan prinsip. Fakta biasanya meliputi istilah (nama), notasi (lambang/simbol), dan lain-lainnya. Sedangkan konsep merupakan ide abstrak yang memungkinkan untuk mengelompokkan objek ke dalam contoh dan non contoh. Skill berkaitan dengan kemampuan siswa dalam memberikan jawaban dan prinsip dapat berupa gabungan konsep dan beberapa fakta.Setelah siswa belajar matematika diharapkan siswa memperoleh keempat hal tersebut.

Salah satu solusi yang ditawarkan untuk mengatasi kesulitan siswa dalam perkalian dan pembagian yaitu dengan metode penjumlahan, dimana dengan metode ini siswa akan lebih mudah mengejakan atau menyelesakan perkalian dan pembagian. Perkalian merupakan proses aritmatika dasar di mana satu bilangan dilipatgandakan sesuai dengan bilangan pengalinya. Secara sederhana dapat dikatakan bahwa perkalian adalah penjumlahan berulang. Begitu pula dengan pembagian. Akan di selesaikan dengan metode penjumlahan yaitu dengan teknik melipatgandakan. Teknik seperti ini pertama di terapkan ketika pada zaman matematika bangsa Mesir Kuno .

Pembelajaran di sekolah bisa dikatakan terbatas. Setiap mata pelajaran sudah ada aturan waktu untuk pembelajarannya. Dengan demikian meskipun siswa-siswi masih membutuhkan perpanjangan waktu dalam proses pembelajaran dikarenakan belum paham betul, pembelajaran harus berganti dengan pelajaran selanjutnya. Maka dari itu masih banyak siswa-siswi yang mengalami kesulitan dalam menangkap materi dari pembelajaran, salahsatunya dari keterbatasan waktu. Salah satu mata pelajaran yang dianggap sulit oleh siswa adalah pelajaran matematika. Tidak sedikit dari siswa-siswa di kelas yang mengalami kesulitan dalam mempelajari pelajaran matematika dengan waktu yang terbatas. Meskipun pelajaran matematika dianggap mata pelajaran yang sulit, tetapi siswa-siswi di SD Plawad masih memiliki keingian dan motivasi yang baik untuk belajar matematika apabila diarahkan dan diberi perlakuan lebih.

Tindakan yang sering sekolah lakukan untuk menangani masalah kesulitan dalam belajar matematika tersebut antara lain : 
(1). Sekolah inisiatif memberikan jam pelajaran tambahan diluar jam pelajaran sekolah. Kendala biasanya pada keterbatasan ketersediaan guru untuk memberikan jam pelajaran tambahan. (2). Sekolah memberikan saran kepasa siswa-siswa untk mengikuti bimbingan belajar diluar sekolah yang dikelola lembaga atau pribadi. Kendala biasanya pada kemmapuan orang tua untuk biayanya dikarenakan relative mahal.

Berdasarkan hal-hal seperti itulah maka kami tim dosen ingin memberikan bimbingan belajar khususnya matematika bagi siswa-siswa sekolah. Pendahuluan menguraikan latar belakang permasalahan yang diselesaikan, isu-isu yang terkait dengan masalah yg diselesaikan, ulasan penelitan/pengabdian yang pernah dilakukan sebelumnya oleh peneliti/pengabdi lain yg relevan dengan penelitian/pengabdian yang dilakukan

\section{Metode}

Sebelum dimulainya kegiatan pelatihan matematika dasar ini dilakukan beberapa tahap persiapan sampai terlaksananya kegiatan. Tahap awal dari kegiatan pengabdian pada masyarakat ini dimulai dari survei ke sekolah dan berdiskusi dengan pihak sekolah mengenai program yanag akan dilaksanakan. Metode yang kami gunakan adalah wawancara langsung dengan guru dan dan kepala sekolah dari sekolah mitra. Wawancara langsung kepada guru dimaksudkan untuk mengetahui materi matematika yang banyak dirasa sulit oleh siswa. Tahap kedua yaitu penyususnan materi yang akan diberikan selama kegiatan ini, yaitu akan membahas materi perkalian dan pembagian yang akan dibuat mudah dengan metode penjumlahan. Dari materi yang sudah dipilih kemudian ditentukan pokok-pokok bahasan yang akan disampaikan dalam pelatihan ini. Dari setiap pokok bahsan pembelajaran diberikan konsep terlebih dahulu kemudian diberikan contoh soal dilanjutkan dengan latihan soal dan terakhir pembahasan soal.

Materi yang diberikan selama pelatihan yaitu tentang materi perkalian dan pembagian. Kegiatan pengabdian pada masyarakat ini menggunakan metode pendidikan dan pelatihan keterampilan melalui ceramah dan demonstrasi. Untuk melihat keberhasilan pelatihan ini, diakhir kegiatan diberikan tes tertulis yang mana sebelum kegiatan juga diberikan tes terlebih dahulu. Tes yang dilakukan sebelum pelatihan dimaksudkan untuk melihat sejauh mana penguasaan orang tua siswa itu terhadap matematika.

\section{Hasil dan Pembahasan}

Pada awal kegiatan, siswa diingatkan kembali tentang dasar-dasar operasi pada matematika yaitu tentang penjumlahan, pengurangan, perkalian dan pembagian. Kegiatan selanjutnya ditambahkan materi-materi yang lebih kompleks seperti penjumlahan pengurangan pada bilangan negatif.

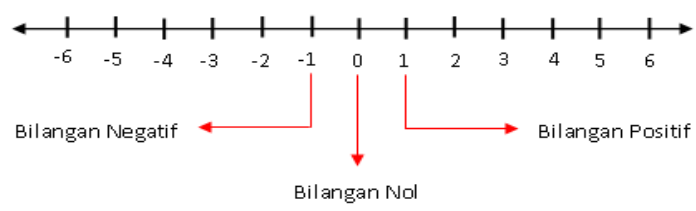

Gambar1.Ilustrasi membuat garis bilangan 
Kesulitan mulai tampak ketika opersai penjumlahan, pengurangan dan pembagian bertemu dengan bilangan negatif. Untuk mengatasi masalah ini maka dijelaskan tentang konsep perkalian bilangan posistif dan negatif.

Tabel 1. Konsep pada bilangan negatif

\begin{tabular}{clllll}
\hline \multicolumn{2}{c}{ Bilangan } & \multicolumn{2}{c}{ Bilangan Kedua } & \multicolumn{2}{c}{ Hasil } \\
Pertama & & & \multicolumn{3}{c}{ Perkalian } \\
\hline Positif & $(+)$ & Positif & $(+)$ & Positif & $(+)$ \\
Negatif & $(-)$ & Negatif & $(-)$ & Positif & $(+)$ \\
Positif & $(+)$ & Negatif & $(-)$ & Negatif & $(-)$ \\
Negatif & $(-)$ & Positif & $(+)$ & Negatif & $(-)$ \\
\hline
\end{tabular}

A. Perkalian

Apa itu Perkalian?

Perkalian artinya menjumlahkan bilangan yang sama sebanyak bilangan pengali. Definisi lebih sederhananya adalah pernjumlahan yang berulang. Misal

4 x 5 itu sama dengan penjumlahan berulang 4 sebanyak 5 kali

$4+4+4+4+4=20$
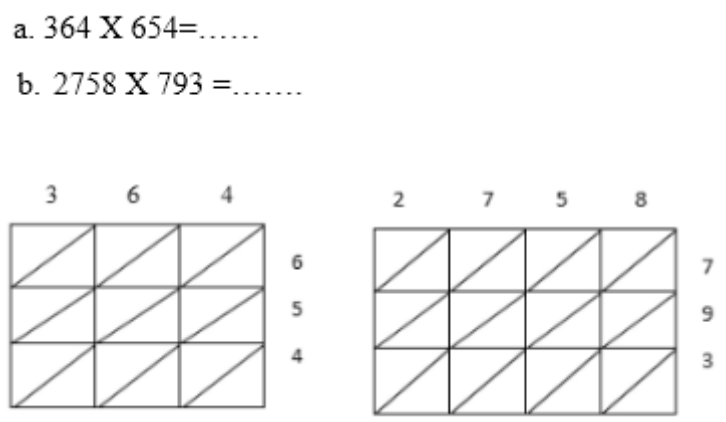

Cara menghitung Mesir Kuno ternyata menggunakan metode yang sekarang banyak digunakan pada computer Misalkan bilangan yang hendak dikalikan ialah 12 × 12, maka bilangan ini selalu dikalikan dengan 2 atau kelipatan 2 .

12

24

48

96

192
1 bilangan yang akan dikalikan

2 bilangan 12 dikalikan 2

*4 hasil kalinya dikalikan 2 lagi

*8 hasilnya dikalikan $2 \mathrm{X}$ juga

16 dan seterusnya dikalikan 2

B. Pembagian

Apa itu Pembagian?

"membagi suatu bilangan dalam beberapa kelompok dengan jumlah yang sama" adalah definisi sederhana dari pembagian. Misanya 10 ekor sapi akan disimpan dalam 2 buah kandang (kelompok) maka operasi matematika dasarnya $10: 2=5$. Contoh lainnya, 40 : 8 itu sama seperti membagi 40 ke dalam 8 kelompok maka setiap kelompok akan beranggotakan 5 . 
Menurut bangsa Mesir Kuno, proses pemecahan pembagian seperti pada proses pengalian yaitu dengan selalu melipatgandakan bilangan pembagi Untuk menghitung 27 : 3 Perhatikanlah langkah-langkah berikut :

$\begin{array}{llll}\text { Langkah ke-1 } & 1 & 3 & \text { bilangan pembagi } \\ \text { Langkah ke-2 } & 2 & 6 & \text { dilipatgandakan } \\ \text { Langkah ke-3 } & 4 & 12 & \text { dilipatgandakan } \\ \text { Langkah ke-4 } & 8 & 24 & \text { dilipatgandakan } \\ \text { Langkah ke-5 } & 16 & 48 & \text { dilipatgandakan } \\ \text { Langkah ke-6 } & 32 & 96 & \text { dilipatgandakan }\end{array}$

Diantara ke-6 langkah ini yang mempunyai unsur 27 ialah

$\begin{array}{lll}\text { Langkah ke-1 } & * 1 & 3 \\ \text { Langkah ke-4 } & * \frac{8}{9}+ & \frac{24}{27}+\end{array}$

Jadi, jelasnya bila 27 dibagi 3 maka hasilnya ialah $1+8=9$

Selama kegiatan pelatihan berlangsung, bermacam macam respon yang ditunjukan siswa-siswa tersebut. Mulai dari yang respon merasa takut sampai yang merasa percaya diri walaupun masih harus banyak bimbingan dalam pelaksanaannya. Dari yang pada mulanya tidak bersemangat tetapi lama lama akhirnya siswa itu merespon baik dan bisa bekerja sama. Mereka bersemangat mengikutikegiatan pelatihan setelah diberikan motivasi bahwa pelatihan ini sangat bermanfaat jika benar benar karena bisa meembantu kelak nanti menghadapi ujian sekolah atau Ujian Nasional. Sesuai dengan ketentuan dalam KBK menurut Sunoto ( dalam pujiati, 2008 : 9) mengatakan bahwa siswa tuntas belajar bila telah $75 \%$ menguasai kompetensi atau sekurang-kurangnya harus mencapai skor 75. Berikut Hasil tes setelah kegiatan pelatihan

Tabel 2. Daftar Nilai hasil Penelitian

\begin{tabular}{|c|c|c|c|c|c|c|c|c|c|c|c|c|}
\hline Nama & S1 & $\mathrm{S} 2$ & S3 & S4 & S5 & S6 & S7 & S8 & S9 & S10 & $\begin{array}{l}\text { Jumlah } \\
\text { skor }\end{array}$ & Nilai \\
\hline yola & 0 & 1 & 1 & 0 & 1 & 1 & 1 & 1 & 0 & 1 & 7 & 70 \\
\hline elisa & 1 & 1 & 1 & 1 & 1 & 1 & 1 & 1 & 1 & 1 & 10 & 100 \\
\hline Yanadi & 1 & 1 & 1 & 1 & 0 & & 1 & 1 & 0 & 1 & 8 & 80 \\
\hline merdini & 1 & 1 & 0 & 1 & 1 & 0 & 1 & 1 & 1 & 1 & 8 & 80 \\
\hline kudrila & 1 & 1 & 1 & 1 & 1 & 1 & 0 & 1 & 1 & 1 & 9 & 90 \\
\hline mona & 1 & 1 & 1 & 1 & 1 & 1 & 1 & 1 & 1 & 1 & 10 & 100 \\
\hline linda & 1 & 0 & 1 & 1 & 1 & 1 & 1 & 1 & 0 & 1 & 8 & 80 \\
\hline agni & 1 & 1 & 1 & 1 & 1 & 1 & 1 & 1 & 1 & 1 & 10 & 100 \\
\hline emilika & 0 & 1 & 1 & 1 & 1 & 1 & 1 & 1 & 1 & 1 & 9 & 90 \\
\hline Lisda & 1 & 1 & 1 & 0 & 1 & 1 & 1 & 1 & 1 & 1 & 9 & 90 \\
\hline sazwa & 0 & 0 & 1 & 1 & 0 & 1 & 1 & 1 & 1 & 0 & 6 & 60 \\
\hline rianty & 0 & 1 & 1 & 1 & 1 & 1 & 1 & 1 & 1 & 0 & 8 & 80 \\
\hline \multicolumn{12}{|c|}{ Rata-rata } & 85 \\
\hline \multicolumn{12}{|c|}{ Persentase keberhasilan } & $100 \%$ \\
\hline
\end{tabular}

Rata-rata nilai dari hasil tes yang didapat setelah pelatihan adalah 8,5 dengan demikian kegiatan pelatihan ini bisa dikatakan berhasil, setiap peserta mampu mengerjakan soal-soal dari tes yang dilaksanakan setelah kegiatan pelatihan berakhir. 
Nilai terendah dengan skor 60 dan skor tertinggi ada yang mencapai 100. Ini merupakan suatu keberhasilan dari para siswa dalam mengikuti pelatihan ini. Dengan adanya kegiatan ini diharapkan dapat membantu mempermudah siswa-siswa dalam belajar matematika yang hapalan perkaliannya kurang.

\section{Kesimpulan}

Berdasarkan hasil pelatihan dan analisis deskripsi data pelatihan diperoleh ratarata dari hasil tes di dapat 85 dengan persentase keberhasilan $100 \%$. Beberapa kesimpulan yang dapat disampaikan terkait dengan hasil pelaksanaan kegiatan dapat diuraikan sebagai beikut, (a) Berdasarkan hasil evaluasi berupa tes tertulis dari sebelum dan sesudah pelatihan terlihat jelas perbedaan hasil nilai yang didapat, artinya pengetahuannya bertambah. (b) berdasarkan wawancara langsung tentang kegiatan ini dengan para siswa, semua peserta merasa senang karena menjadi lebih paham dan mengerti serta menjadi mudah dalam mengerjakan perkalian dan pembagian. (c) berdasarkan evaluasi prograam yang dilaksanakan, program yang dirancang ternyata sudah sesuai dengan tujuan yang ingin dicapai

\section{Daftar Pustaka}

Dantes, N. (2014). Landasan Pendidikan : Tinjauan dari Dimensi Makropedagogis. Yogyakarta: Graha Ilmu.

Helmawati. (2019). Pembelajaran dan Penilaian Berbasis HOTS. Bandung. Remaja Rosdakarya.

Permendikbud Nomor 61 Th 2014 Lampiran 1. Pedoman Pengembangan Kurikulum Tingkat Satuan Pendidikan (2014)

Russefendi, E.T. (2006). Pengantar Kepada Membantu Guru Mengembangkan Kompetensinya Dalam Pengajaran Matematika Untuk Meningkatkan CBSA. Bandung: Transito.

Supadi. (2017 ). Pendalaman Materi FOKUS US/M SD/MI. Surabaya : Wahyu Media

Tim MKPBM. (2001). Strategi Pembelajaran Matematika Kontemporer. Bandung: JICA 